\title{
ROLE OF T-786C ENDOTHELIAL GENE POLYMORPHISM OF NO - SYNTHASE IN THE DEVELOPMENT OF ACUTE CONTRAST-INDUCED NEPHROPATHY IN PATIENTS WITH CORONARY HEART DISEASE
}

\author{
Graduate student, Sagynbaeva G. A., \\ Doctor of Medical Sciences, Professor, Kaliev R. $R$. \\ Department of Faculty Therapy, \\ The Kyrgyz State Medical Academy named after I.K. Akhunbaev, Kyrgyzstan, Bishkek
}

DOI: https://doi.org/10.31435/rsglobal_wos/28022020/6921

\section{ARTICLE INFO}

Received: 19 December 2019

Accepted: 22 February 2020

Published: 28 February 2020

\section{KEYWORDS}

gene polymorphism, nitric oxide,

chronic renal failure, endothelial dysfunction, contrast-induced nephropathy.

\begin{abstract}
Contrast-induced nephropathy (CIN) is the third considerable cause of acute kidney injury (AKI) and makes up almost $10 \%$ of all acute kidney failure (AKF) cases.

Objective. To study the role of polymorphism of eNOS-gene in the development of acute contrast-induced nephropathy (CIN) in case of coronary heart disease.

Materials and methods. The prospective study was conducted in the National Cardiology and Therapy Center named after academician Mirsaid Mirahimov from 2015 to 2018 . A total of 184 patients with coronary heart disease (CHD) aged 33-70 years (average age 55.2 \pm 8.5 years) were examined to determine possible associative relationships between eNOS gene polymorphism (T786C) and the development of acute CIN. Of these, the group without CIN was 152 , and with the CIN there were 32 patients who underwent coronary angiographic examination (CAG). Radiopaque contrast agents Ultravist (Iopromide) and Omnipack (Iohexol) were used. CIN was defined as an increase in serum creatinine (Scr) concentration by more than $25 \%$ from the initial level or by more than $0.5 \mathrm{mg} / \mathrm{dL}(44.2$ $\mu \mathrm{mol} / \mathrm{L}$ ) and a decrease in glomerular filtration rate (GFR) after administration of an iodinated contrast agent within 48-72 hours in the absence of other reasons. A molecular genetic study was conducted to determine the T-786C polymorphism of the eNOS gene.

Results. The genotype frequency of the TT gene in the group with CIN was $87.5 \%$, and in the group without CIN $69.7 \%$, the reliability was $p$ $<0.05$. But the connection of acute CIN with the genotypes of TS and SS was not observed in both of the groups.

Conclusions. TT genotype T-786C polymorphism of the eNOS gene is a risk factor for the development of acute contrast-induced in patients with coronary heart disease.
\end{abstract}

Citation: Sagynbaeva G. A., Kaliev R. R. (2020) Role of T-786C Endothelial Gene Polymorphism of NO - Synthase in the Development of Acute Contrast-Induced Nephropathy in Patients with Coronary Heart Disease. International Academy Journal Web of Scholar. 2(44). doi: 10.31435/rsglobal_wos/28022020/6921

Copyright: (C) 2020 Sagynbaeva G. A., Kaliev R. R. This is an open-access article distributed under the terms of the Creative Commons Attribution License (CC BY). The use, distribution or reproduction in other forums is permitted, provided the original author(s) or licensor are credited and that the original publication in this journal is cited, in accordance with accepted academic practice. No use, distribution or reproduction is permitted which does not comply with these terms.

Contrast-induced nephropathy (CIN), also called contrast-induced acute kidney damage (CI-AKI), is an iatrogenic disease that occurs after administration of an iodinated contrast agent in the absence of other causes [1,2], which appears as an AKI that occurs in within 24-72 hours after intravenous or intraarterial administration of X-ray contrast agents (CSWs), the diagnostic criteria of which are an increase in 
serum creatinine by $\mathrm{SCr} \geq 0.5 \mathrm{mg} / \mathrm{dL}(\geq 44 \mu \mathrm{mol} / \mathrm{L})$ or more than $25 \%$ of the initial level within 48 hours after the contrast agent administration, returning to the initial level within 10-14 days [3].

In 2004, Gleeson and Bulugahapitiya [4] indicated that CIN is the third considerable cause of acute kidney failure (AKF) that developes in the hospital after invasive procedures and hypotension, and causes $12 \%$ of all AKI-cases in the hospital. Very often CIN develops in patients suffering from heart diseases after percutaneous coronary intervention (PCI) and makes up around 49\%, since repeated injections of a contrast agent are required [5]. So, in coronary heart disease (CAD), manifestations of CIN, according to some data, are already initially associated with the presence of different risk factor combinations, namely, diabetes mellitus, arterial hypertension, age [6,7]. At the same time, in our opinion, the features of nephropathy induction by contrast and changes in the subsequent prognosis of the coronary heart disease (CAD) itself are not completely disclosed.

Endothelial NO synthase (Type III, NOS-3, eNOS) is a key enzyme that is involved in the homeostatic control of vascular tone, glomerular microcirculation and other processes [8]. Thus, the disregulation of this enzyme is one of the factors for the development of CIN.

As it is known, the eNOS gene generates vasoprotective NO molecules [9], is localized on chromosome 7q35-36, has 26 exons, 25 introns, and encodes the protein with the molecular weight of $135 \mathrm{kDa}$, consisting of 1203 amino acids [10,11]. Polymorphism of the eNOS gene is considered one of the main predisposing factors for endothelial dysfunction which is observed with CIN $[12,13]$. However, the role of the eNos gene polymorphism genetic factor for the development and severity of CIN has not been fully disclosed.

Objective: To study the role of endothelial NO synthase gene polymorphism in the development of acute contrast-induced nephropathy in coronary heart disease.

Materials and methods: The prospective study was conducted in the National Cardiology and Therapy Center named after academician Mirsaid Mirahimov at the Ministry of Health of the Kyrgyz Republic from 2015 to 2018. A total of 184 patients with coronary heart disease (CHD) aged 33-70 years (average age 55.2 \pm 8.5 years), among them male were $132(71,7 \%)$, female -52 , were examined to determine possible associative relationships between eNOS gene polymorphism (T786C) and the development of acute CIN in patients with CHD. Of these, the group without CIN was 152, and with the CIN there were 32 patients who underwent coronary angiographic examination (CAG). Radiopaque contrast agents Ultravist (Iopromide) and Omnipack (Iohexol) were used.

All the patients most often suffered from various forms of coronary heart disease (CHD) (Table 1.) and acute coronary syndrome (ACS). As follows from it, including 26 patients with acute myocardial infarction, 104 patients with unstable angina, 26 patients had signs of chronic heart failure. The most common concomitant pathology was arterial hypertension $(64.1 \%)$, obesity $(32.6 \%)$, and kidney cysts $(13.0 \%)$.

Table 1. Forms of coronary heart disease among the examined patients.

\begin{tabular}{|l|c|c|}
\hline \multicolumn{1}{|c|}{ CHD forms } & $\mathrm{n}$ & $\%$ \\
\hline Stable effort angina & 44 & $23,9 \%$ \\
\hline Unstable angina & 104 & $56,5 \%$ \\
\hline $\begin{array}{l}\text { Vasospastic angina pectoris } \\
\text { (Prinzmetal's angina) }\end{array}$ & 2 & $1,1 \%$ \\
\hline Microvascular angina & 8 & $4,3 \%$ \\
\hline Acute myocardial infarction & 26 & $14,1 \%$ \\
\hline Atherosclerotic cardiosclerosis & 2 & $1,1 \%$ \\
\hline Postinfarction cardiosclerosis & 24 & $13,0 \%$ \\
\hline Chronic cardiac aneurysm & 10 & $5,4 \%$ \\
\hline Chronic heart failure (CHF) & 26 & $14,1 \%$ \\
\hline
\end{tabular}

Type of study: case-control. The patients were divided into 2 groups. The first group included 32 patients who, after endovascular intervention for coronary heart disease, developed contrastinduced nephropathy $(\mathrm{CIN})$. The second group included 152 patients without $\mathrm{CIN}$. The patients of both groups underwent a full clinical examination with the clarification of complaints, medical history and physical examination, anthropometric and biochemical studies, including determination of total cholesterol, sugar, creatinine, transaminases, serum electrolytes, as well as troponin and creatinine 
clearance according to the CKD-EPI formula [14]. The polymorphism of the eNOS gene was studied, electrocardiographic and echocardiographic examination, ultrasound of the kidneys and CAG were performed. In addition, the risk of CIN developing was calculated in all the patients according to the Mehran R scale (2004) [6] (Table 2).

Table 2. The risk scale for the development of contrast-induced nephropathy after percutaneous coronary intervention.

\begin{tabular}{|l|c|}
\hline Risk factors & Scale index \\
\hline Hypotension & 5 \\
\hline Application of IABC & 5 \\
\hline Chronic heart failure (CHF) & 5 \\
\hline Age over 75 years & 4 \\
\hline Anemia & 3 \\
\hline Diabetes mellitus & 1 for every $100 \mathrm{ml}$ \\
\hline Volume of contrast agent & 4 \\
\hline Serum creatinine more than $1.5 \mathrm{mg} / \mathrm{dL}$ or GFR (according to & 2 with GFR from 40 to 60 \\
MDRD) less than $60 \mathrm{~min} / 1.73 \mathrm{~m}^{2}$ & 4 with GFR from 20 to 40 \\
& 6 with GFR less than 20 \\
\hline
\end{tabular}

\begin{tabular}{|c|c|c|}
\hline Total index & CIN risk & Hemodialysis risk \\
\hline Low ( $\leq 5$ points $)$ & $7,5 \%$ & $0,04 \%$ \\
\hline Avarage $(6-10$ points $)$ & $14 \%$ & $0,12 \%$ \\
\hline High $(11-15$ points $)$ & $26,1 \%$ & $1,09 \%$ \\
\hline Very high ( $\geq 16$ points) & $57,3 \%$ & $12,6 \%$ \\
\hline
\end{tabular}

Note: IABC-intraaortic balloon counterpulsation; GFR (according to MDRD) - glomerular filtration rate (according to the Modification of Diet in Renal Disease Study).

Prior to being included into the study, all the participants gave their written informed consent.

The study of the polymorphic locus of the e-NOS gene was carried out at the Scientific Research Institute of Molecular Biology and Medicine at the National Cardiology and Therapy Center named after academician Mirsaid Mirahimov at the Ministry of Health of the Kyrgyz Republic.

Blood sampling and extraction of genomic DNA. For the molecular genetic studies, genomic deoxyribonucleic acid (DNA) was used, extracted from venous blood containing $0.5 \mathrm{M}$ EDTA as an anticoagulant. DNA was isolated from the blood by the standard phenol-chloroform extraction method. $5 \mathrm{ml}$ of whole blood was added with 9 volumes of sucrose buffer $(0.32 \mathrm{M}$ sucrose, $10 \mathrm{mM}$ Tris- $\mathrm{HCl} \mathrm{pH}$ 8.0, $5 \mathrm{mM} \mathrm{MgCl2}, 1 \%$ Triton X-100), incubated for $40 \mathrm{~min}$. on ice. Leukocyte nuclei were precipitated at $5000 \mathrm{rpm}$./min., washed twice with buffer $(10 \mathrm{mM}$ Tris- $\mathrm{HCl} \mathrm{pH} \mathrm{8.0,75}$ $\mathrm{mM} \mathrm{NaCl})$. The precipitate was resuspended in $1 \mathrm{ml}$ of buffer $(75 \mathrm{mM} \mathrm{NaCl}, 24 \mathrm{mM}$ EDTA) with the addition of SDS to $0.5 \%$ and 200 units of proteinase $\mathrm{K}$, incubated at $37^{\circ} \mathrm{C}$ all night long. Protein components after treatment with lysis buffers were removed by standard phenol-chloroform extraction: 1 treatment with an equal volume of phenol, 2 - phenol-chloroform mixture (1: 1), 1 chloroform. DNA was precipitated from the aqueous phase by adding 2.5 volumes of $96 \%$ ethanol, the DNA residue was washed with a 70\% ethanol solution, dried in air and dissolved in bidistilled water.

Polymorphism of the lengths of restriction fragments (PCR-RFLP).

Patient genotyping at polymorphic C789T loci of the e-NOS gene was carried out by PCRRFLP method. The PCR reaction was carried out in the volume of $20 \mu 1$ in a Px2 Thermal Cycler (Thermo Electron Corporation, USA). The composition of the reaction mixture included: GoTaq polymerase (Promega, USA); 5x Green PCR buffer, $\mathrm{pH}=8.5,7.5 \mathrm{mM} \mathrm{MgCl} 2$ solution (final concentration of $\mathrm{Mg}^{2+}$ ions - $1.5 \mathrm{mM}$ ); $2.0 \mathrm{mM}$ dNTP mixture solution (Promega); a mixture of forward and reverse primers at the concentration of $5.0 \mu \mathrm{m}$ (Promega).

The restriction products were separated on a $3 \%$ agarose gel for 50 minutes at a constant voltage of $120 \mathrm{~V}$ in a $1 \times \mathrm{TBE}$ solution. Ethidium bromide solution was used to visualize the DNA 
fragments on an agarose gel. Analysis of the electrophoretic separation of PCR products was carried out by a gel-documenting system Gel-Doc-It, UVP (Bio-Rad, USA).

Determination of genotypes and alleles of the polymorphic locus C789T of the e-NOS gene. To amplify the polymorphic locus T786C of the eNOS gene, the following primers were used: 5'-GGTGTACCCCACCTGCATTCT 3' and 5'-CACCCCCACCCTGTCATTC - 3'. PCR amplification products were treated with Turbo NAE endonuclease.

The results of PCR and restriction were detected on a 4\% agarose gel and photographed with the gel-documenting system Gel-Doc-It, UVP (Bio-Rad) (Fig. 1).

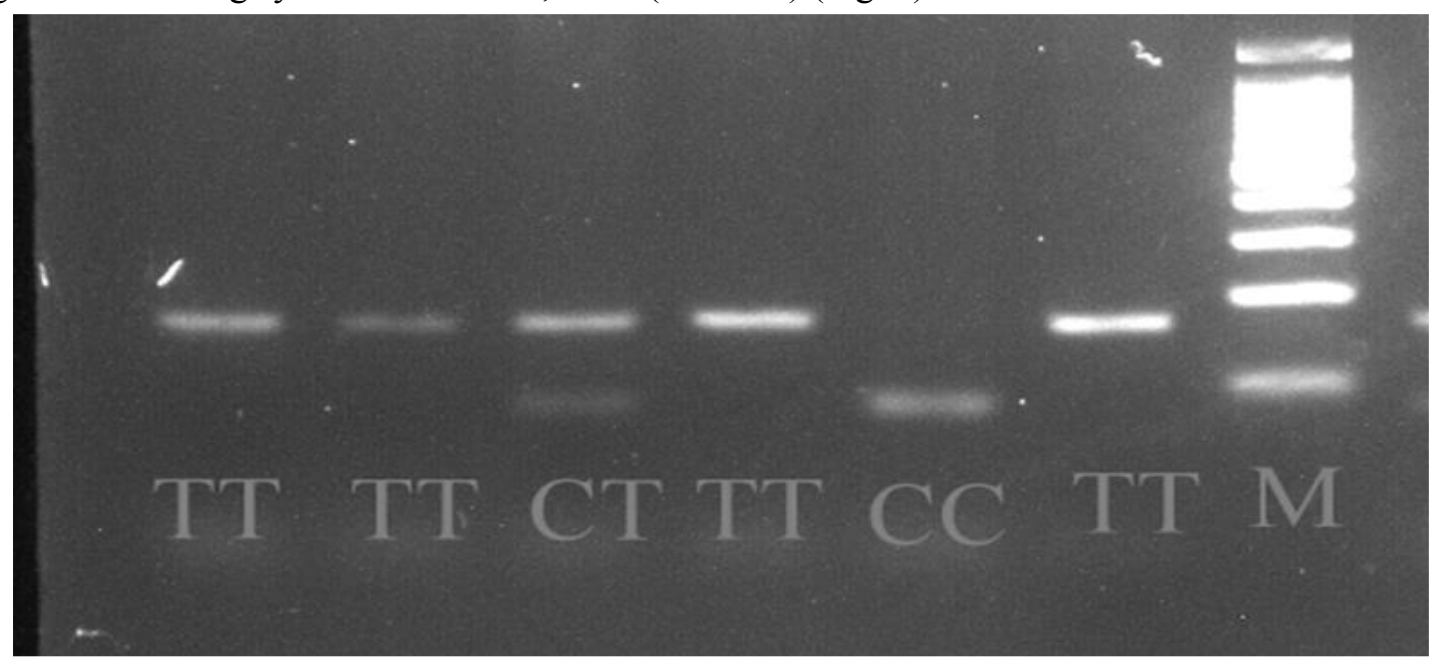

Fig. 1. Electrophoretic separation of the genotypes of the T786C polymorphic locus of the eNOS gene in a 3\% agarose gel, where to the TT genotype corresponds the 164 bps DNA fragment, CT - 164 bps and $82 \mathrm{bps}$, and SS - $82 \mathrm{bps} . \mathrm{M}$ - DNA marker of molecular balance 100-1000 bps.

Statistical processing of the obtained data was carried out with the help of the standard statistical software package STATISTICA 6.0. The normality of the distribution was determined by Shapiro-Wilk and Lillefors criteria. The data are presented in the form of $\mathrm{M} \pm \sigma$ with a normal distribution of the attribute and in the form of Me (25 and 75 percentile) - with an asymmetric distribution. The reliability of the differences between the groups was determined with the help of the non-parametric Mann-Whitney and Kolmogorov-Smirnov criteria, as well as the Student t-parameter test. For multiple comparisons, the Kruskal-Wallis criteria and analysis of variance were used with the calculation of the coefficient $\mathrm{F}$ and subsequent post-hoc analysis. Contingency tables were used to assess a qualitative attribute. The qualitative data are presented as the absolute number of patients with this symptom and a percentage of their number in the group. To assess the correspondence of the distributions of genotypes to the expected Hardy-Weinberg equilibrium values and to compare the frequencies of genotypes and alleles in the samples of the sick and healthy, the $\chi^{2}$ criterion was used. The associations of alleles and genotypes with a predisposition to the disease were evaluated by the odds ratio (OR). The study of the interdependence between the indicators was carried out using correlation analysis with the calculation of the Spearman correlation coefficient (r). Differences were considered significant when a probability of $\mathrm{p}<0.05$ was reached.

Results. We studied the frequency of contrast-induced nephropathy in patients with coronary heart disease during endovascular interventions when contrast agents - iopromide (Ultravist) and Omnipack (Iohexol) were used. Wherein, it turned out that the development of CIN according to the criteria given in the chapter "Material and Methods" took place in 32 patients out of the 184 patients included in the study, i.e. the occurrence of $\mathrm{CIN}$ in the examined group was $17.4 \%$. But there was not a single case where renal replacement therapy $(0 \%)$ was required for correction of renal impairment. The estimated incidence of CIN in the examined patients according to the Mehran scale was: for the development of contrast-induced AKI $-8.2 \pm 2.6 \%$, for AKI, which required hemodialysis $-0.06 \pm 0.11 \%$.

Thus, the incidence of CIN in patients with coronary heart disease during endovascular interventions using the contrast agent - iopromide (Ultravist) and iohexol (Omnipack) in our study was slightly higher than the estimated one and amounted to $17.4 \%$. 
All the examined patients with CHD were divided into 2 groups. The 1st group included 32 patients who, after endovascular intervention for coronary heart disease, developed CIN. The 2nd group included 152 patients without CIN development.

Table 3. Comparative incidence of various forms of coronary heart disease among patients with/without contrast-induced nephropathy

\begin{tabular}{|l|c|c|c|}
\hline \multicolumn{1}{|c|}{ CHD forms } & CIN+ & CIN - & $\mathrm{p}$ \\
\hline Stable effort angina & $10(31,3 \%)$ & $34(22,3 \%)$ & $\mathrm{NS}$ \\
\hline Unstable angina & $10(31,3 \%)$ & $114(75 \%)$ & $<0,001$ \\
\hline $\begin{array}{l}\text { Vasospastic angina pectoris } \\
\text { (Prinzmetal's angina) }\end{array}$ & $2(6,3 \%)$ & $0(0 \%)$ & $\mathrm{NS}$ \\
\hline Microvascular angina & $2(6,3 \%)$ & $6(3,9 \%)$ & $\mathrm{NS}$ \\
\hline Acute myocardial infarction & $8(25 \%)$ & $18(11,8 \%)$ & $<0,05$ \\
\hline Atherosclerotic cardiosclerosis & $2(6,3 \%)$ & $4(2,6 \%)$ & $\mathrm{NS}$ \\
\hline Postinfraction cardiosclerosis & $4(12,5 \%)$ & $26(17,1 \%)$ & $\mathrm{NS}$ \\
\hline Chronic heart aneurysm & $4(12,5 \%)$ & $6(3,9 \%)$ & $<0,05$ \\
\hline Chronic heart failure (CHF) & $8(25 \%)$ & $46(30,2 \%)$ & $\mathrm{NS}$ \\
\hline
\end{tabular}

Note: NS - differences between groups are not significant

When analyzing the features of the occurrence of CHD forms in the selected groups, the following data were obtained. It turned out that the patients, who had had CIN, were much more likely to suffer from acute myocardial infarction $(25 \%$ versus $11.8 \%, \mathrm{p}<0.05)$, as well as chronic heart aneurysm $(12.5 \%$ versus $3.9 \%, \mathrm{p}<0,05)$. At the same time, in the presence of acute forms of coronary heart disease, their less severe course was revealed in this group of patients in the form of unstable angina $(31.3 \%$ versus $75 \%$ in the group without $\mathrm{CIN}, \mathrm{p}<0.001)$. In terms of the frequency of occurrence of other CHD forms, the selected groups did not differ significantly ( $p>0.05)$.

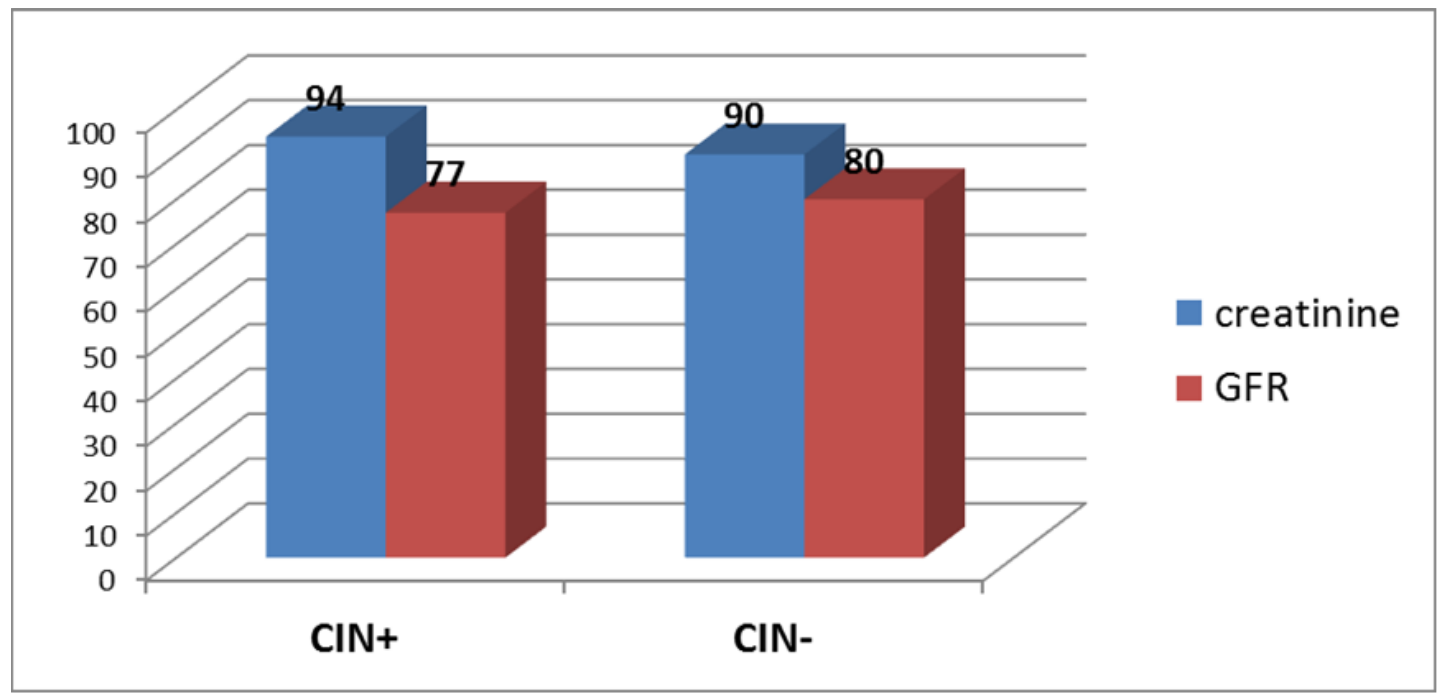

Fig. 2. The state of the initial renal filtration function in the patients suffering from coronary heart disease with / without the development of contrast-induced nephropathy

When analyzing the initial state of kidneys function and their filtration ability, it turned out that the groups of patients with/without CIN did not differ in creatinine level ( $p>0.05)$, as well as glomerular filtration rate (GFR) ( $p>0.05$ ) (Fig. 3.1.). So, in the patients with CIN, serum creatinine level was $94 \pm 15 \mu \mathrm{mol} / \mathrm{L}$, and in the patients without CIN, $90 \pm 15 \mu \mathrm{mol} / \mathrm{L}$ (p>0.05). Similarly, GFR indices in the indicated groups were $77 \pm 24 \mathrm{ml} / \mathrm{min}$ and $80 \pm 13 \mathrm{ml} / \mathrm{min}(\mathrm{p}>0.05)$ respectively.

When analyzing the state of kidneys function and their filtration ability after 48-72 hours after $\mathrm{CAG}$, it turned out that the groups of patients with/without CIN differed in creatinine level ( $p>0.05)$ and glomerular filtration rate (GFR) ( $>$ > 0.05) (Fig. 4.0.). So, in the patients with CIN, serum creatinine level was $131 \pm 41 \mu \mathrm{mol} / \mathrm{L}$, but in the patients without CIN $-90 \pm 16 \mu \mathrm{mol} / \mathrm{L}(\mathrm{p}>0.05)$. Similarly, GFR indices in the indicated groups were $56 \pm 19 \mathrm{ml} / \mathrm{min}$ and $75 \pm 13 \mathrm{ml} / \mathrm{min}(\mathrm{p}>0.05)$ respectively.

As follows from the data presented in Fig. 3.3., our distribution of alleles of the eNOS gene demonstrates a significant predominance of the frequency of the T-allele occurrence (T-allele - $84.2 \%$, 
$\mathrm{C}$-allele $-15.8 \%$ ). The representation of the eNOS gene genotypes among the patients examined by us was $72.8 \%$ for the TT genotype, $22.8 \%$ for the TS genotype, and $4.4 \%$ for the SS genotype. The observed distribution of the genotypes was in Hardy-Weinberg equilibrium (Fig. 3.4.)

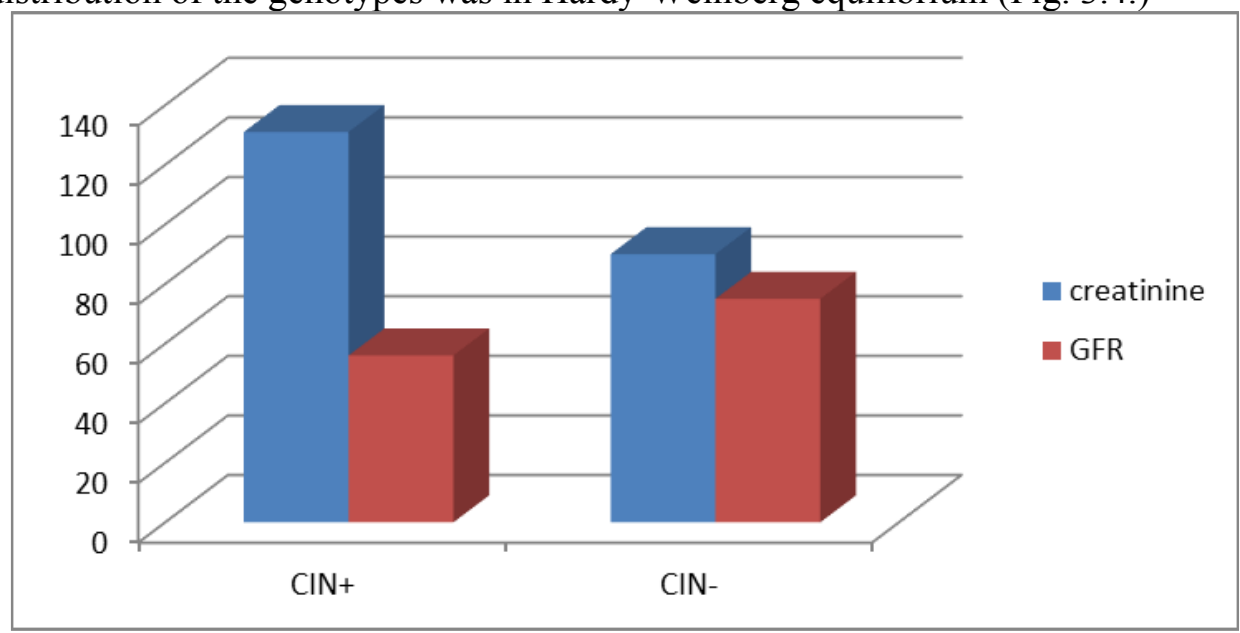

Fig 3. State of renal filtration function in the patients with coronary heart disease with/without the development of contrast-induced nephropathy in 48 hours after CAG.

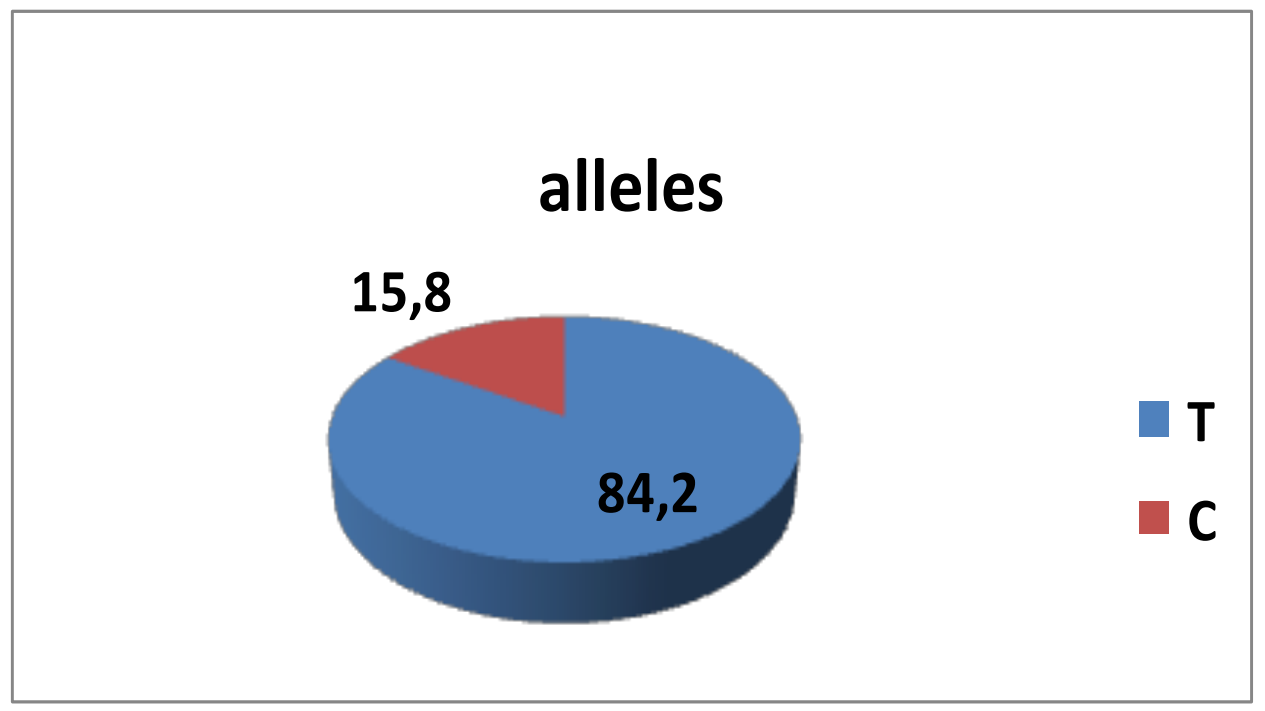

Fig. 4. Allele frequency (in \%) of the endothelial nitroxide synthetase gene among the examined patients of the general group

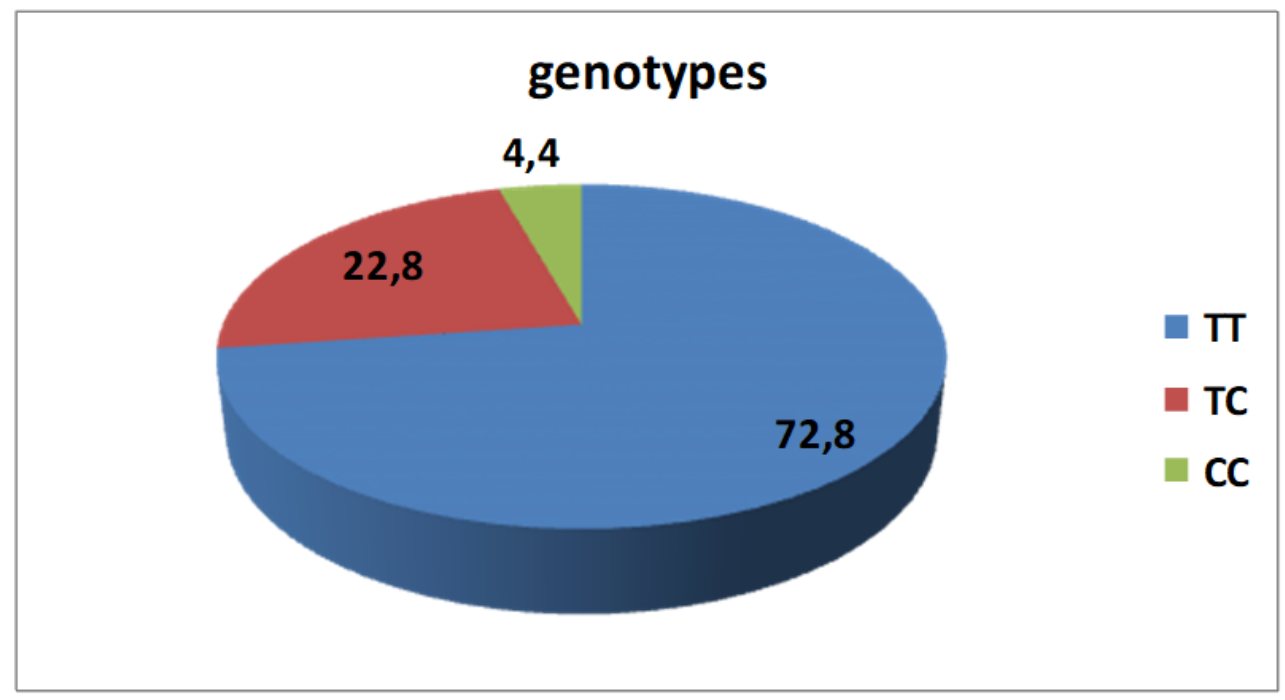




\section{Fig. 5. The frequency of occurrence of genotypes (in \%) of the endothelial nitroxide synthetase gene among the examined patients of the general group.}

The comparative analysis of the frequencies of the alleles of the eNOS gene among the patients with coronary heart disease with/without CIN demonstrated an association of these allelic variants with the development of $\mathrm{CIN}$ after endovascular interventions $\left(\chi^{2}=5.28, \mathrm{p}=0.02\right)$. So, the frequency of the $\mathrm{T}$ allele in the group of patients with CIN was $93.75 \%$ and was significantly higher than the frequency of this allele in the group of patients with coronary heart disease without CIN $(82.2 \%, \mathrm{p}=0.02)$. In contrast, the frequency of the $\mathrm{C}$ allele in the patients with CIN was significantly lower $(6.25 \%$ versus $17.8 \%, \mathrm{p}=0.02)$.

Table 4. Allele and genotype frequency of the endothelial nitroxide synthetase gene in patients with coronary heart disease with/without contrast-induced nephropathy

\begin{tabular}{|l|c|c|c|c|}
\hline Alleles and genotypes & CIN + & CIN - & $\chi^{2}$ & $\mathrm{p}$ \\
\hline Allele T & $60(93,75 \%)$ & $250(82,2 \%)$ & \multirow{2}{*}{$\chi^{2}=5,28, p=0,02$} & $=0,02$ \\
\hline Allele C & $4(6,25 \%)$ & $54(17,8 \%)$ & & $=0,02$ \\
\hline TT & $28(87,5 \%)$ & $106(69,7 \%)$ & \multirow{2}{*}{$\chi^{2}=4,21, \mathrm{p}=0,04$} & $<0,05$ \\
\hline TC & $4(12,5 \%)$ & $38(25 \%)$ & & NS \\
\cline { 1 - 2 } CC & 0 & $8(5,3 \%)$ & & NS \\
\hline
\end{tabular}

Note: NS - differences are not significant

The analysis of the frequency distribution of genotypes in the selected groups also demonstrated the presence of an association with the development of CIN in the patients with coronary heart disease after endovascular interventions $\left(\chi^{2}=4.21, \mathrm{p}=0.04\right)$. In particular, the incidence of TT genotype among the patients with CIN at $87.5 \%$ was significantly higher than in the patients without CIN $(69.7 \%, \mathrm{p}<0.05)$. The prevalence of the other genotypes (TS and SS) in the compared groups did not significantly differ ( $\mathrm{p}>0.05)$.

Thus, carriage of the T allele in the homozygous variant (TT genotype) is associated with the development of contrast-induced nephropathy in the patients with coronary heart disease after endovascular interventions.

The discussion. We have studied the possibility of associative links between the polymorphism of the eNOS gene (T786C) and the development of acute CIN in the patients with coronary heart disease during endovascular interventions.

For the diagnosis of CIN, we used the criteria proposed by the KDIGO 2012 Working Group and described in the «Material and Methods» section.

The main objective of our study was to study the interdependence of the C789T e-NOS gene with the development of CIN in the patients with coronary heart disease after endovascular interventions.

The discovery of endothelium-derived hyperpolarizing factor that was identified in 1980 as nitric oxide (NO) (Furchgott R.F., Zawadski J.V., 1980) [15], determined the interest in vascular endothelial function, as well as the development of a new area of research, endothelial dysfunction, as the main factor of the pathogenesis of vascular changes and the need for its therapeutic correction.

NO has a wide range of biological effects: it participates in the work of central and autonomic nervous systems, in the regulation of cardiovascular activity, in the functioning of gastrointestinal and genitourinary tract, in the work of secretory tissues and respiratory organs. The cytostatic and/or cytotoxic activity of NO, which can occur at its high concentrations, indicates its role in the cellular immunity system. This function determines the effect of NO on the processes of apoptosis and initiation (Reutov V.P., 2000) [16].

The synthesis of NO from L - arginine is carried out under the influence of the three main isoforms of the NO-synthases enzyme (NOS): neuronal (nNOS), endothelial (eNOS) and inducible (iNOS). In their active form, all the three isoforms are homodimers with the molecular weight of 130 (iNOS), 135 (eNOS) and 160 (nNOS) kDa (Reutov V.P., 2000; Andrew P.J., Mayer B., 1999) [16,17]. nNOS and eNOS are constitutive, that is, they are constantly transcribed in neuronal and endothelial cells, respectively. The level and activity of the enzyme depends on the allelic variant of the eNOS genes.

A series of meta-analyzes is devoted to the association of eNOS gene polymorphism and kidney disease. So, in 2015 the interdependence between Glu298Asp polymorphism of the eNOS gene and the progression of chronic kidney disease (CKD) in the patients with established heart failure (HF) was studied. Chand S. et al. (2015) [18] examined 140 patients who underwent magnetic resonance 
imaging (MRI) of the heart and tissue doppler echocardiography. Two clinical trials revealed that the presence of Glu298Asp rs1799983 polymorphism of the eNOS gene is a significant risk factor for the progression of chronic renal failure (CRF) among the patients with established HF.

In contrast to the above data, Ilhan N. et al. (2016) [19] studied the Glu298Asp eNOS gene polymorphism and endothelial dysfunction in the patients with and without end-stage RF (ESRF) and did not reveal any interdependence between the Glu298Asp eNOS gene polymorphism and ESRF in the group of patients under examination. In the work of Marson B.P. et al. [20] eNOS gene polymorphism and its haplotypes were also not associated with the presence of ESRF.

Thus, the incidence of TT genotype among the patients with CIN at $87.5 \%$ was significantly higher than in the patients without CIN $(69.7 \%, \mathrm{p}<0.05)$. At the same time, the prevalence of the other genotypes (TS and SS) in the compared groups did not significantly differ $(p>0.05)$.

\section{REFERENCES}

1. Berns A.S. Nephrotoxicity of contrast media. Kidney Int. 1989; 36:730-740;

2. Rich M.W., Crecelius C.A. Incidence, risk factors, and clinical course of acute renal insufficiency after cardiac catheterization in patients 70 years of age or older. A prospective study. Arch. Intern. Med. 1990; 150: 1237-1242.

3. Andreucci M., Solomon R., Tasanarong A. Side effects of radiographic contrast media: pathogenesis, risk factors and prevention. BioMed Research International. Volume 2014, Article ID 741018, 1- 20 pages. http://dx.doi.org/10.1155/2014/741018

4. Gleeson T. G., Bulugahapitiya S. Contrast-induced nephropathy. American Journal of Roentgenology. 2004;183(6):1673-1689.

5. Nash K., Hafeez A., Hou S. Hospital acquired renal insufficiency Am. J. Kidney Dis. - 2002. - Vol. 39. - P. 930-936

6. Mehran R., Aymong E.D., Nikolsky E. et al. A simple risk score for prediction of contrast-induced nephropathy after percutaneous coronary intervention: development and initial validation. J. Am. Coll.Cardiol. 2004; 44: 1393-1399.

7. Bartholomev B.A., Harjai K.J., Dukkipati S. et al. Impact of nephropathy after percutaneous coronary intervention and a metod for risk stratification. Am. J. Cardiol. 2004; 93:1515-1519.

8. Forstermann U., Closs E. I., Pollock J. S. et al. Nitric oxide synthase isozymes: characterization, purification, molecular cloning, and functions. Hypertension 1994; 23: 1121-1131.

9. Forstermann U., Munzel T. Endothelial Nitric Oxide Synthase in Vascular Disease: From Marvel to Menace. Circulation 2006; 113: 1708-1714.

10. Massion P. B., Feron O., Dessy C. et al. Nitric oxide and cardiac function: ten years after, and continuing. Circ Res. 2003; 93: 388-398.

11. Fischmann T. O., Hruza A., Niu X. D. et al. Structural characterization of nitric oxide synthase isoforms reveals striking active-site conservation. Nat. Struct. Biol. 1999; 6 (3): 233-42.

12. Volgina G.V. Contrast - induced nephropathy. Radiology - Practice 2007; 6: 42-53.

13. Tumlin J., Stacul F., Adam A. et al. Pathophisiology of contrast-induced nephropathy. Am.J.Cardiol. 2006; 98:14K-20K

14. Andrew S. Levey, Lesley A. Stevens, Christopher H. Schmid. et al. A New Equation to Estimate Glomerular Filtration Rate. Ann Intern Med. 2009 May 5; 150(9): 604-612.

15. Furchgott R.F., Zawadski J.V. The obligatory role of endothelial cells in relaxation of arterial smooth muscle by acetylcholine. Nature 1980; 288: 373-376.

16. Reutov V.P. Biomedical aspects of nitric oxide and superoxide anionradical cycles. Vestn. Academy of Medical Sciences of Ukraine 2000; 3: 35-41.

17. Andrew P.J., Mayer B. Enzymatic function of nitric oxide synthases. Cardiovasc. Res. 1999. 43: 521-531

18. Chand S., Chue C.D., Edwards N.C. et al. Endothelial nitric oxide synthase single nucleotide polymorphism and left ventricular function in early chronic kidney disease. PLOS ONE 2015; 22(10): 1-10.

19. Ilhan N., Ates K., Ilhan N. et al. eNOS Glu298Asp Polymorphism and Endothelial Dysfunction in Patients with and without End-stage Renal Disease. Balkan Med J. 2016; 33(2): 128 - 37.

20. Marson B.P., Dickel S., Ishizawa M.H. et al. Endothelial nitric oxide genotypes and haplotypes are not associated with end-stage renal disease. DNA Cell Biol. 2011; 30(1): 55 - 9. 